\title{
EQUILIBRIUM
}

Quarterly Journal of Economics and Economic Policy

VOLUME 7 ISSUE 1, 2012

ISSN 1689-765X

\author{
Anna Wildowicz-Giegiel ${ }^{*}$ \\ University in Biatystok, Poland
}

\section{Intellectual Capital and InNovativeness of Polish Enterprises in the Context of EUROPE 2020 STRATEgy GoALS}

JEL Classification Codes: 031,032

Keywords: intellectual capital, enterprise innovativeness, perspectives of Polish economy development

\begin{abstract}
From the majority of European Union documents it explicitly follows that innovations are a key to the economic future of Europe. Innovativeness, understood as a propensity to create new or modernize the existing solutions, and the ability to absorb foreign scientific or technological achievements, is extremely important for the Polish economy. Unfortunately, both innovation activity of enterprises and the results obtained in this field by the Polish economy have not been satisfactory so far. The main purpose of this study is to present the issue of innovation in Polish enterprises, significantly influenced by intellectual capital. It is commonly known that all intangible assets possessed by a society, i.e. all the components of intellectual capital, including human, structural and social assets, currently play an important role in the process of creating innovation. The analysis of the relation between the innovativeness of economic entities and the quality of Poland's intellectual capital was done in the light of the basic assumptions of the renewed Lisbon Strategy and the Europe 2020 Strategy.
\end{abstract}

(C) Copyright Nicolaus Copernicus University Press

Date of Submission: March 1, 2011; date of acceptance: October 5, 2011

* Contact: e-mail: awildowicz@interia.pl, Uniwersytet w Białymstoku, Wydział Ekonomii i Zarządzania, ul. Warszawska 63, 15-062 Białystok, Poland 


\section{INTRODUCTION}

The beginning of the $21^{\text {st }}$ century is the time when the EU-27 countries, including Poland, face numerous civilisational challenges. The financial crisis and the resultant economic slowdown, as well as social and environmental dangers have forced the European community to increase the efforts aimed at the development of knowledge and innovation, without which the EU can find it extremely difficult to maintain the rapid pace of growth.

Also the Polish economy must face the development challenges. Its long-term growth will largely depend on the ability to utilise the existing resources of intellectual capital and, even more so, on the amount of investment in increasing this capital. Since innovation is the driving force of modern economies, appropriate institutional conditions should be ensured to foster creativity. Moreover, the Poles should be made aware of the fact that the accumulation of intellectual capital is a prerequisite for maintaining the pace of economic modernisation and improving the living standards. Without it, neither an increase in the innovation performance of Polish enterprises nor an improvement in their international competitive capacity are possible.

The primary aim of this paper is to discuss the question of innovation in Polish enterprises, with particular attention to intellectual capital - the key determinant of innovation. The presented analysis of the link between enterprise innovation and the quality of intellectual capital existing in Poland was performed in the light of the basic assumptions of the renewed Lisbon Strategy and the Europe 2020 Strategy.

\section{THE PREMISES OF EUROPE 2020 STRATEGY}

The Europe 2020 Strategy is part of the effort to prepare the EU economy for the inevitable development challenges of the next decade. The previous European ten-year development plan adopted during the European Council summit of March 2000 proved unfeasible. For this reason, Europe failed to bridge the gap to the United States and to become the most dynamic knowledge-based economy in the world. Due to the great diversity of institutional frameworks, as well as a lack of coherent and consistent policy which would give priority to common goals over the particular interests of the member states, attempts to overcome the tensions and conflicts of the Lisbon Strategy were unsuccessful. The failure can be blamed on the overly ambitious, sometimes contradictory, objectives of the Strategy, such as the creation of the most competitive economy on the one hand and the building of a European social model, accompanied by radical economic reforms, on 
the other. That is why at the spring summit of the EU Council in 2005 it was decided to revise the ineffectively implemented and disappointing policies. Among the main new goals there was a reduction of the numerous priorities concerning the economic, social and ecological spheres, along with the overambitious indicators of their implementation. Instead, two main objectives were selected: to boost European innovation and to strive for higher employment rates. The provisions regarding growth and employment strategy regarded mainly the need to provide an impetus to the economic development of the EU (Grosse 2006, p. 6). Therefore, the adopted solutions included steps towards increasing expenditure on R\&D and on SME innovation, which would eventually result in greater innovativeness, on both regional and local scales. It is worth mentioning that public aid was, above all, allocated to the development of human resources, including organisation of professional training courses, labour market activation and the improvement of educational systems.

Unfortunately, the implementation of the ambitious objectives of the Lisbon Strategy in particular member states did not end in success. This is confirmed by the data in Table 1 .

Table 1. Lisbon Strategy implementation - results for selected EU-27 countries

\begin{tabular}{|c|c|c|c|c|c|c|c|c|c|c|}
\hline \multirow{2}{*}{ Country } & \multicolumn{2}{|c|}{ Overall } & \multicolumn{2}{c|}{$\begin{array}{c}\text { Information } \\
\text { society }\end{array}$} & \multicolumn{2}{c|}{$\begin{array}{c}\text { Innovation } \\
\text { and R\&D }\end{array}$} & \multicolumn{2}{c|}{$\begin{array}{c}\text { Enterprise } \\
\text { network }\end{array}$} & \multicolumn{2}{c|}{$\begin{array}{c}\text { Sustainable } \\
\text { development }\end{array}$} \\
\cline { 2 - 12 } & rank & result & rank & result & rank & result & rank & result & rank & result \\
\hline Sweden & 1 & 5.83 & 1 & 6.20 & 2 & 5.64 & 2 & 6.19 & 1 & 6.57 \\
\hline Finland & 2 & 5.72 & 5 & 5.51 & 1 & 6.12 & 8 & 5.96 & 3 & 6.19 \\
\hline Germany & 6 & 5.39 & 9 & 5.27 & 4 & 5.10 & 1 & 6.49 & 2 & 6.19 \\
\hline France & 8 & 5.22 & 10 & 5.21 & 9 & 4.62 & 3 & 6.17 & 9 & 5.54 \\
\hline $\begin{array}{c}\text { Great } \\
\text { Britain }\end{array}$ & 9 & 5.15 & 4 & 5.61 & 7 & 4.71 & 9 & 5.77 & 10 & 5.48 \\
\hline $\begin{array}{c}\text { Czech } \\
\text { Republic }\end{array}$ & 15 & 4.71 & 17 & 4.43 & 13 & 4.02 & 20 & 5.11 & 16 & 4.96 \\
\hline Spain & 18 & 4.53 & 20 & 4.21 & 15 & 3.93 & 14 & 5.37 & 15 & 5.06 \\
\hline Lithuania & 20 & 4.39 & 19 & 4.38 & 20 & 3.76 & 19 & 5.11 & 19 & 4.73 \\
\hline Hungary & 21 & 4.28 & 22 & 4.12 & 18 & 3.79 & 21 & 4.85 & 22 & 4.50 \\
\hline Poland & 24 & 4.07 & 26 & 3.50 & 22 & 3.64 & 26 & 4.12 & 23 & 4.49 \\
\hline Italy & 25 & 4.03 & 23 & 3.70 & 19 & 3.78 & 22 & 4.81 & 24 & 4.28 \\
\hline Bulgaria & 27 & 3.77 & 24 & 3.63 & 27 & 3.12 & 25 & 4.23 & 26 & 3.82 \\
\hline EU-27 & - & 4.81 & - & 4.73 & - & 4.23 & - & 5.39 & - & 5.16 \\
\hline USA & - & 5.27 & - & 5.79 & - & 6.03 & - & 5.73 & - & 4.59 \\
\hline
\end{tabular}

Source: Own analysis based on The Lisbon Review (2010, p. 8). 
The following countries were the definite leaders in the implementation of the Lisbon Strategy in the years 2002-2010: Sweden, Finland, Denmark, Holland, Luxembourg, Germany, Austria, France, Great Britain and Belgium. Bulgaria, Romania and Italy were the least successful. Poland also ranked rather low - in the $24^{\text {th }}$ position. It should be stressed that the most significant differences in the Strategy's implementation could be observed in four key areas: information society, innovation and R\&D, enterprise networks and sustainable development (The Lisbon 2010, p. 8). The presented results confirm that an ever increasing gap persists between the EU27 member states and the USA, which, despite the ambitious assumptions of the Lisbon Strategy, has not been bridged. Nevertheless, according to the European Commission, the Strategy enabled a consensus to be reached on the necessity of further reforms in the indicated priority areas. As a result, it delivered tangible benefits for business and society, e.g. a rise in employment rates, elimination of bureaucratic obstacles to entrepreneurship, better choices for consumers.

Globalisation, growing demand for natural resources and the ageing of societies have forced the EU-27 countries to devise a new conception of the European economy, embodied in the Europe 2020 Strategy, also known as the Strategy for smart, sustainable and inclusive growth. The global economic and financial crisis made it clear that the shortcomings of the Lisbon Strategy implementation must be addressed. The new Strategy provides the right framework to ensure that. It indicates three interconnected priorities (Strategy 2010, p. 5):

- smart growth based on knowledge and innovation;

- sustainable growth: support for economy that makes efficient use of resources, is more environmentally-friendly, but also more competitive;

- inclusive growth: a high-employment economy delivering economic, social and territorial cohesion.

To make these priorities a reality, it is necessary to take measures at national, EU and international levels. Those actions should focus on overcoming the structural weaknesses of the European economy. The aforementioned priorities should be realised by means of efficient tools, tailored to the characteristics of particular regions. Previous experience shows that it is not always possible to successfully emulate solutions used in other countries. Hence, the Strategy assumes that the objectives should: (i) revolve around a common theme; (ii) be measurable; (iii) reflect the variations in economic structures and preferences of the member states; (iv) be based on sufficiently reliable data. The adopted goals include (The Lisbon, p. 3):

- increasing the employment rate to $75 \%$;

- boosting the spending on research and development to 3\% of GDP;

- attaining an up to $30 \%$ reduction of carbon dioxide emissions; 
- cutting the school dropout rate to below $10 \%$ and expanding the share of younger people with a university degree to $40 \%$;

- lifting 20 million people out of poverty.

Bearing in mind the assumptions of the Europe 2020 Strategy, it can be concluded that achieving the EU priorities certainly requires greater attention to the intellectual capital as investment in education and technology is believed nowadays to be indispensable for dynamic growth. It seems that high quality human, social and structural capital will make it possible to accelerate European economic convergence and help Europe's economy gain competitive advantage in the future. All the member states which take on the challenge of the Europe 2020 Strategy should be fully aware of this fact.

\section{INNOVATION OF POLISH ENTERPRISES}

Research conducted by various academic institutions and government agendas has shown that the level of innovation in the Polish economy (measured by such standard indicators as $R \& D$ expenditure, number of innovating firms, export of technologically advanced products or number of patents) is relatively low in comparison with the other EU-27 countries. Although according to EIS 2009, Poland slightly rose in the ranking, joining the group of so-called moderate innovators, in the majority of criteria, regarding both innovation expenditure and outputs, we are far below the EU average (European 2009, p. 6).

The low innovation rates of Polish enterprises are reflected, for instance, in the results of research on innovation published annually by GUS (Central Statistical Office). This research demonstrates that the share of companies which introduced product or process innovation in the years 2006-2008 was lower than the same indicator for the previously studied period, which is 2004-2006.

Table 2. Share of enterprises which introduced product or process innovation in years 2006-2008 (in \%)

\begin{tabular}{|l|c|c|c|}
\hline \multirow{2}{*}{ Specification } & \multicolumn{3}{c|}{$\begin{array}{c}\text { Enterprises with number } \\
\text { of employees }\end{array}$} \\
\cline { 2 - 4 } & $\mathbf{1 0 - 4 9}$ & $\mathbf{5 0 - 2 4 9}$ & Over 249 \\
\hline \multicolumn{1}{|c|}{ Industry overall } & $\mathbf{1 4 . 6}$ & $\mathbf{3 2 . 7}$ & $\mathbf{6 0 . 7}$ \\
\hline Mining & 9.6 & 24.3 & 46.9 \\
\hline Processing industry & 14.7 & 33.0 & 60.7 \\
\hline $\begin{array}{l}\text { Generation and distribution of electric energy, gas and } \\
\text { water }\end{array}$ & 11.3 & 30.3 & 63.4 \\
\hline
\end{tabular}


Table 2 continued

\begin{tabular}{|l|c|c|c|}
\hline \multirow{2}{*}{ Specification } & \multicolumn{3}{c|}{$\begin{array}{c}\text { Enterprises with number } \\
\text { of employees }\end{array}$} \\
\cline { 2 - 4 } & $\mathbf{1 0 - 4 9}$ & $\mathbf{5 0 - 2 4 9}$ & Over 249 \\
\hline \multicolumn{1}{|c|}{ Service sector overall } & $\mathbf{1 2 . 5}$ & $\mathbf{2 5 . 0}$ & $\mathbf{4 7 . 7}$ \\
\hline $\begin{array}{l}\text { Wholesale and commission sale (excluding motor } \\
\text { vehicles and motorcycles) }\end{array}$ & 10.4 & 21.5 & 41.4 \\
\hline $\begin{array}{l}\text { Transport, other supporting land transport activities, } \\
\text { tourism activities }\end{array}$ & 8.2 & 13.8 & 38.3 \\
\hline Postal and telecommunication services & 26.1 & 47.9 & 95.2 \\
\hline Financial agency services & 34.7 & 44.1 & 62.0 \\
\hline Information technology & 27.3 & 53.7 & 67.4 \\
\hline $\begin{array}{l}\text { Architectural and engineering activities; technical } \\
\text { testing and analysis }\end{array}$ & 13.7 & 26.5 & 52.4 \\
\hline
\end{tabular}

Source: Działalność innowacyjna (GUS 2009).

The total percentage of enterprises which introduced product or process innovation in 2006 stood at $10.8 \%$ and $32.7 \%$ respectively, and did not differ dramatically from the EU average. At the same time, such innovation leaders as Sweden or Finland had far more firms which had implemented novel solutions. In Finland, these indicators were $19.7 \%$ and $44.6 \%$, while in Sweden - 16.3\% and 51.3\% (Europe 2010 p. 604). In this context, Poland's innovation efforts seem decidedly inadequate. What is more, the majority of innovation activities undertaken in Poland are of imitative nature. Also, the share of high-technology sector is modest in comparison with the most competitive economies. Research and development - regarded as a critical factor of technological advancement of particular branches - is one of the most important types of innovation activity. Meanwhile, a report by KPMG, analysing the R\&D sector in Poland, states that, because of the considerable risks involved, R\&D efforts are usually undertaken by large firms - as about $60 \%$ of the studied firms admitted. According to a study by M. Juchniewicz (Diagnoza 2010), micro enterprises rarely became involved in $R \& D$. It should be noted that most of the innovators fully appreciate the role of $R \& D$ in creating new product/services or streamlining the existing ones. In spite of this, investment in $R \& D$ is not interpreted as a way to achieve comparative advantage. KPMG found that in the 1000 most innovating firms of the EU, the average level of R\&D expenditure amounted to $2.3 \%$ of total sales. Meanwhile in Poland, only one in five companies exceeded this average. What is, therefore, the innovation level of Polish enterprises? The 2009 Report on Innovation of Polish Economy („Raport o innowacyjności gospodarki Polski w 2009”) includes data that indicate some positive trends in the field of the innovation process. For instance, several Polish firms have joined the ranking of top R\&D investors 
in Europe. The 2008 list of 1000 European R\&D leaders includes such Polish firms as BRE Bank (453), Bioton (534), Telekomunikacja Polska (559), Netia (705), Asseco Poland (542) and Orlen (949). It is widely known that the most innovating branches in the EU-27 are: the pharmaceutical industry, the biotechnology industry and the advanced information technology sector (The 2009 EU Industrial, p. 33). For these companies, R\&D plays a key role and determines their competitive position. Unfortunately, in Poland, the number of innovators in these three branches is relatively small when compared with the most competitive world economies.

The relatively low expenditure on $\mathrm{R} \& \mathrm{D}$ is the greatest weakness of the innovation performance of Poland. Consequently, the results are far below the EU-27 average. The data from 2006 show that the private sector's R\&D investment was merely $0.18 \%$ of the GDP. In contrast, during the same period, R\&D expenditure by American private firms reached $1.83 \%$ of the GDP (Europe 2010, p. 492). It follows from data collected by the Central Statistical Office that in 2008, private enterprises spent PLN 2046.1 million on $\mathrm{R} \& \mathrm{D}$, i.e. ca. one third of the total expenditure of all sectors. Meanwhile, in developed countries, the share of private companies in financing $\mathrm{R} \& \mathrm{D}$ is nearly two thirds of the total expenditure (Nauka i technika, p. 40). Considering merely the volume of $\mathrm{R} \& \mathrm{D}$ input, one can observe significant regional disparities, which is illustrated in Table 3.

In 2009, the following voivodeships spent the most on R\&D: Mazowieckie, Małopolskie, Pomorskie, Wielkopolskie. At the same time, in Lubuskie, Opolskie, Świętokrzyskie, Podlaskie, Zachodniopomorskie and Warmińsko-Mazurskie this kind of expenditure was much lower. Having compared the levels of expenditure to the number of applications to the European Patent Office, one can notice that Mazowieckie and Małopolskie are leaders in both categories - they invest the most in R\&D and patent the greatest number of inventions.

The relatively poor innovation performance of Poland is a direct result of the dramatically low R\&D expenditure. It should be noted that both product and process innovations in years 2006-2008 were usually introduced by large enterprises, employing above 249 persons. It is common knowledge that big firms possess greater capital potential - both tangible and non-tangible - and thus have better opportunities to build their competitive position based on innovation. However, it is small and medium enterprises that comprises approximately $99.8 \%$ of the economy. That is why an assessment of the level of innovation in Polish firms should focus on smaller entities, which have far more limited accumulation capacities, and, inevitably, much worse development opportunities, particularly as far as the risk-involving innovative activity is concerned. 
Table 3. R\&D and innovation performance in 2009

\begin{tabular}{|c|c|c|c|c|c|}
\hline \multirow{2}{*}{ Specification } & \multicolumn{3}{|c|}{$\begin{array}{l}\text { R\&D expenditure (cur- } \\
\text { rent prices) }\end{array}$} & \multirow{2}{*}{$\begin{array}{l}\text { Proportion of } \\
\text { industrial } \\
\text { enterprises } \\
\text { which in- } \\
\text { vested in } \\
\text { innovation } \\
\text { in } \%\end{array}$} & \multirow{2}{*}{$\begin{array}{c}\text { Proportion of } \\
\text { service enterpris- } \\
\text { es which invested } \\
\text { in innovation } \\
\text { in } \%\end{array}$} \\
\hline & $\begin{array}{c}\text { overall } \\
\text { in } \%\end{array}$ & $\begin{array}{c}\text { per } \\
\text { person } \\
\text { in } \\
\text { PLN }\end{array}$ & $\begin{array}{l}\text { share } \\
\text { in } \\
\text { GDP }\end{array}$ & & \\
\hline Poland & 100,0 & 237,6 & 0,60 & 14,4 & 11,6 \\
\hline Dolnośląskie & 6,4 & 202,1 & 0,44 & 17,5 & 8,7 \\
\hline $\begin{array}{l}\text { Kujawsko- } \\
\text {-Pomorskie }\end{array}$ & 3,8 & 167,6 & 0,22 & 13,8 & 10,3 \\
\hline Lubelskie & 3,3 & 137,0 & 0,48 & 14,1 & 8,6 \\
\hline Lubuskie & 0,3 & 28,7 & 0,10 & 11,0 & 6,7 \\
\hline Łódzkie & 5,4 & 193,9 & 0,54 & 10,6 & 7,8 \\
\hline Małopolskie & 10,2 & 279,7 & 0,95 & 15,9 & 10,2 \\
\hline Mazowieckie & 38,6 & 669,8 & 1,21 & 13,7 & 15,5 \\
\hline Opolskie & 0,8 & 6,3 & 0,14 & 14,7 & 17,4 \\
\hline Podkarpackie & 2,1 & 39,9 & 0,37 & 18,9 & 10,7 \\
\hline Podlaskie & 0,7 & 55,7 & 0,26 & 15,3 & 7,6 \\
\hline Pomorskie & 4,4 & 178,2 & 0,57 & 15,5 & 9,6 \\
\hline Śląskie & 10,5 & 206,1 & 0,36 & 16,9 & 13,9 \\
\hline Świętokrzyskie & 1,6 & 115,5 & 0,27 & 12,6 & 5,2 \\
\hline $\begin{array}{l}\text { Warmińsko- } \\
\text {-Mazurskie }\end{array}$ & 1,3 & 81,0 & 0,23 & 13,4 & 7,4 \\
\hline Wielkopolskie & 9,3 & 248,2 & 0,52 & 12,8 & 12,4 \\
\hline Zachodniopomorskie & 1,3 & 70,0 & 0,24 & 11,1 & 12,1 \\
\hline
\end{tabular}

Source: Regiony (2011, p. 24), Działalność (2010, p. 23).

There is a need for greater public awareness of the fact that the problem of comparatively low rates of innovation in enterprises must be promptly dealt with, in order to speed up the modernisation of the Polish economy and to close the development gaps between regions. Increased innovation would undoubtedly facilitate the attainment of the objectives of the Europe 2020 Strategy.

\section{INTELLECTUAL CAPITAL AS STIMULUS FOR INNOVATION IN POLISH ECONOMY}

As the experience of many countries shows, economic success, and the resultant strong competitive position in the global market, increasingly 
depends on a society's level of knowledge. The new model of postindustrial economy uses different determinants of competitiveness. It turns out that the accumulated intellectual capital, i.e. people who are welleducated, cooperative, creative, inclined to innovate, and who can count on the support of broadly defined institutional infrastructure, is a prerequisite for economic and social progress. In line with this approach, the chief premises of the Europe 2020 Strategy include the need to build competitive advantage on the basis of knowledge and innovation. Importantly, in order to achieve this, there must be improvement in the quality of education, R\&D efficiency, knowledge transfer support policies and the degree of utilisation of available information and communication technologies. In this context, one should mention numerous challenges inherent to the realisation of the ambitious goals of this strategy.

It is commonly known that intellectual capital nowadays plays a tremendously important role in the process of effective transformation of knowledge into new market-ready products, technologies or organisational solutions. Interpreted as a pool of knowledge (be it individual, organisational or social), intellectual capital enables smooth functioning of economic entities and thus contributes to better efficiency of these entities. According to the definition by OECD, intellectual capital is the economic value of two categories of intangible assets of a company: organisational (structural) capital and human capital. The latter usually refers to human, structural and relational resources (Guidelines, pp. 10-11). Each of these components can be analysed on enterprise, branch or national levels. Table 4 presents various classifications of human capital.

Table 4. Selected classifications of human capital

\begin{tabular}{|c|c|c|c|}
\hline Annie Brooking & Nick Bontis & $\begin{array}{l}\text { Erick-Karl } \\
\text { Sveiby }\end{array}$ & Thomas Stewart \\
\hline $\begin{array}{l}\text { Human assets } \\
\text { Market assets } \\
\text { Organisational assets } \\
\text { Intellectual property }\end{array}$ & $\begin{array}{l}\text { Human capital } \\
\text { Structural capital } \\
\text { Relational capital }\end{array}$ & $\begin{array}{l}\text { Employee compe- } \\
\text { tence } \\
\text { Internal structure } \\
\text { External structure }\end{array}$ & $\begin{array}{l}\text { Human capital } \\
\text { Internal structural } \\
\text { capital } \\
\text { External structural } \\
\text { capital } \\
\text { Customer capital }\end{array}$ \\
\hline Gerard Petrash & $\begin{array}{c}\text { Leiv Edvinsson } \\
\text { Michael S. Malone }\end{array}$ & Patrick H. Sullivan & Mark McElroy \\
\hline $\begin{array}{l}\text { Human capital } \\
\text { Organisational capi- } \\
\text { tal } \\
\text { Customer capital }\end{array}$ & $\begin{array}{l}\text { Human capital } \\
\text { Structural capital }\end{array}$ & $\begin{array}{l}\text { Human capital } \\
\text { Intellectual assets } \\
\text { Intellectual property }\end{array}$ & $\begin{array}{l}\text { Human capital } \\
\text { Social capital } \\
\text { Structural capital }\end{array}$ \\
\hline
\end{tabular}

Source: Own analysis based on Ujwary-Gil (2010, p. 97); McElroy (2002, p. 32). 
Rankings show that Poland has for many years been among the least innovative economies of the EU-27. The greatest discrepancies are observed as regards enterprise innovation. This poor innovation performance calls for a thorough examination of its causes. It is doubtless that enterprise innovation, defined as a capability to introduce novel solutions, is determined by a complex pattern of numerous factors. However, a closer analysis of the ongoing transformation of the world economy reveals that it is intellectual capital that spurs innovation and entrepreneurial success.

Since innovation is a kind of creative destruction, human capital - as the creative element - seems to be of immense importance. Employers' knowledge, experience and skills, their openness to new ideas and their risk capacity are the chief determinants of innovation in an enterprise. The structure and the level of education of the Polish society would seem to indicate that our country's human capital still remains at the stage of extensive development. As a result, a qualitative regression can be observed, which takes the form of a mismatch between the education system and the requirements of the innovation economy. This is confirmed by e.g. the insufficient number of science and technology students, as well as inadequate social awareness of the role that scientific knowledge plays in economic development. Admittedly, statistical data from 2006 show an evident increase in the rate of science and engineering graduates aged 20-29 (per 1000 persons); it reached $13.3 \%$, which is slightly more than the EU average (Progress 2008, p. 77). Nevertheless, GUS studies into human capital confirm that Polish graduates lack in the ability to acquire new skills and scientific knowledge. A growing number of firms struggle with shortages of qualified professionals, i.e. workers who possess highly specialised knowledge and competencies - as many as $44 \%$ of respondents quoted this as their major problem (Stan 2008, p. 10). In Poland, another obstacle to the development of employee competence and skills is the insufficient understanding of idea of lifelong learning. In 2007, the percentage of people aged 25-64 who participated in education or training activities was merely 5.1\%, whereas the EU average was almost twice as high (Progress 2008, p. 27).

In innovation, an important role is played by structural capital, usually embodied in technical, organisational or IT infrastructure. The value of structural capital largely depends on R\&D and ICT expenditure. Meanwhile, the Polish enterprise sector's share in R\&D financing was, in 2007, only $34.3 \%$, while the EU-27 average amounted to 55\%, and in the USA and Japan the indicators were as high as $66.4 \%$ and $77.7 \%$ respectively (Nauka i technika 2010). The utilisation of modern information and telecommunication technologies in Polish firms is also unsatisfactory. It has to be noted, however, that in 2008, 93\% of entrepreneurs had Internet access, and 59\% were using a broadband connection (Społeczeństwo 2010, pp. 
47-49). It is worth emphasising that greater investment in structural capital could bring an increase in the number of patents, licenses and utility models. This is extremely important since Eurostat data for 2006 show that the Polish ratio of 3.4 patents per 1 million inhabitants was nearly 70 times as low as the same indicator for Finland and almost 127 times lower than that for Switzerland (Diagnoza 2009, pp. 94-95). In the face of the necessity of improving innovation efficiency, structural capital, i.e. infrastructure in the broad sense of the word, should be expanded. In this way, it would be possible to take full advantage of the intellectual potential of employees and thus accelerate the processes of knowledge creation and absorption in Polish enterprises.

Social capital is another, equally valuable, component of intellectual capital. According to McElroy (2003), innovation, understood as a form of social activity, manifests itself in social innovation capital, i.e. the ability of a firm's employees to spontaneously organize themselves in order to create and use innovation. Thanks to correct interpersonal relations, it is possible to generate, integrate and apply new knowledge for the purpose of innovative activity. However, many researchers point to the fundamental weaknesses of Polish social capital, namely the high degree of distrust among the population and low efficiency of inter-sector cooperation. It should be emphasised that such cooperation is quite rare and its value for the Polish economy is negligible. Meanwhile modern economics regards cooperation as an indispensable condition of innovation. In 2006, more than half of the entrepreneurs in Cyprus, Finland, Lithuania and Slovakia declared cooperation for innovative development. Although Poland's 48.2\% result seems quite good when compared against the EU-27 average, the general level of innovation in the country still leaves much to be desired (Quality 2009, p. 4).

The exceptionally low international mobility of Polish academics and students reflects the quality of the social capital potential of our country. Statistics demonstrate that in the years 2007/2008 the percentage of students who participated in the international exchange programme Erasmus was only $0.60 \%$, which ranked Poland $24^{\text {th }}$ out of 30 countries involved in the scheme (Diagnoza 2009, p. 111). The mobility of university teachers also seems to be extremely low. In 2008, they used the Erasmus opportunity nearly twice as rarely as their EU colleagues.

\section{CONCLUSIONS}

High quality intellectual capital, and the ability to transform its components into value, are absolute prerequisites for knowledge-based economic 
growth and the resultant competitive edge. This is of particular significance, not only to Europe but also to the Polish economy, which, in spite of numerous setbacks in the implementation of the Lisbon Strategy, is striving to overcome the structural weaknesses by investing in knowledge and innovation in order to speed up modernisation and narrow the development gap. For this reason, the new Europe 2020 Strategy mentions the necessity of acting towards intelligent and sustainable development, and explicitly emphasises that such development is impossible without enhancing intellectual capital, thus upgrading the innovation capacity of businesses, understood as the ability to introduce new ideas and to apply novel technological or organisational solutions.

Because of the relatively poor innovation performance of Polish enterprises, reflected in the unsatisfactory results of innovation activity, particularly in the number of innovating companies, science-business cooperation and commercialisation of $R \& D$ output, it is vital that new innovationfriendly institutional solutions be implemented. But, above all, it is necessary to address the need to improve the quality of intellectual capital. The realisation of the ambitious goals of the Europe 2020 Strategy depends, to a large extent, on the size of investment in intellectual capital, which requires raising the level of education, competence and trust in the society, as well as raising the awareness of the role of knowledge and innovation in economic growth.

To sum up, statistical data from both Eurostat and GUS confirm that considerable deficiencies exist in all the categories of intellectual capital, which seriously hampers the innovation process in the Polish economy. Improvement in the quality of intellectual capital, being a source of potential competitive advantages, is an essential condition for increasing the innovation performance of Polish enterprises. This will certainly contribute to the delivery of the key priorities of the Europe 2020 Strategy, since a rise in innovation and competitive capacity will help provide a solid foundation for economic growth and social welfare.

\section{LITERATURE}

Baczko T. (2009), Raport o innowacyjności gospodarki Polski w 2009 roku - Synteza wyników badań, INE PAN, Warszawa.

Czy warto inwestować $w$ innowacje? Analiza sektora badawczo-rozwojowego $w$ Polsce (2009), Raport KPMG.

Diagnoza stanu szkolnictwa wyższego w Polsce (2009), Ernst\&Young oraz Instytut Badań nad Gospodarką Rynkowa, Warszawa.

Działalność innowacyjna przedsiębiorstw w latach 2006-2009 (2010), GUS, Warszawa. 
Europe in Figures (2010), Eurostat Yearbook, Luxemburg.

European Innovation Scoreboard (EIS) 2009 (2010), European Commission.

Europa 2020. Strategia na rzecz inteligentnego i zrównoważonego rozwoju sprzyjajq̨cego właczeniu społeczneти (2010), Komisja Europejska, Bruksela.

Grosse T.G. (2006), Nowe podejście do strategii lizbońskiej. Czy uda się przezwyciężyć sprzeczności europejskiego kapitalizmu? „Analizy i Opinie”, nr 34, Instytut Spraw Publicznych.

Guidelines for Managing and Reporting on Intangibles (Intellectual Capital Report). Meritum Project (2001), European Commission, Brussels.

Juchniewicz M. (2010), Diagnoza innowacyjności mikroprzedsiębiorstw w Polsce - omówienie wyników badań empirycznych, PSDB, Warszawa.

McElroy M.W. (2002), Social Innovation Capital, „Journal of Intellectual Capital”, Vol. 3, No.1.

Monitoring Industrial Research: The 2009 Industrial R\&D Investment Scoreboard (2009), European Commission, Luxemburg.

Nauka i technika w Polsce w 2008 roku (2010), GUS, Warszawa.

Polska 2030. Wyzwania Rozwojowe (2009), Kancelaria Prezesa Rady Ministrów, Warszawa.

Progress Towards the Lisbon Objectives in Education and Training (2008), Commission staff working document, Commission of the European Communities.

Quality in the Focus of Innovation (2009), ,Statistics in Focus”, No. 33.

Ranking najbardziej innowacyjnych firm w Polsce (2009), Kamerton Innowacyjności 2008, PKPP Lewiatan i BRE Bank, Warszawa.

Regiony Polski (2011), GUS Warszawa.

Społeczeństwo informacyjne w Polsce. Wyniki badań statystycznych z lat 20042008 (2010), GUS, Warszawa.

The Lisbon Review 2010. Towards a More Competitive Europe?(2010), World Economic Forum.

Ujwary-Gil (2010), Kapitat intelektualny - problem interpretacji kluczowych terminów, „Organizacja i Kierowanie”, nr. 2. 
